\title{
Fluorescence polarization-based rapid detection system for salivary biomarkers using modified DNA aptamers containing base-appended bases
}

Hirotaka Minagawa, ${ }^{\dagger}$ Akihisa Shimizu, ${ }^{\dagger}$ Yuka Kataoka, ${ }^{\ddagger}$ Masayasu Kuwahara, ${ }^{*}{ }^{\ddagger}$ Shintaro Kato,${ }^{\dagger}$ Katsunori Horii, ${ }^{\dagger}$ Ikuo Shiratori, ${ }^{* \dagger}$ and Iwao Waga ${ }^{\dagger}$

$\dagger$ NEC Solution Innovators, Ltd., 1-18-7, Shinkiba, Koto-Ku, Tokyo 136-8627, Japan

$\$$ Graduate School of Integrated Basic Sciences, Nihon University, 3-25-40 Sakurajosui, Setagaya-ku, Tokyo 156-8550, Japan

\author{
*Corresponding Author \\ Ikuo Shiratori \\ NEC Solution Innovators, Ltd., \\ 1-18-7, Shinkiba, Koto-Ku, Tokyo 136-8627, Japan, phone +81 35534 2619, fax +81 355342620 \\ E-mail: iku-shiratori@xc.jp.nec.com
}

Masayasu Kuwahara

Graduate School of Integrated Basic Sciences, Nihon University,

3-25-40 Sakurajosui, Setagaya-ku, Tokyo 156-8550, Japan, phone +81 353179398

E-mail: mkuwa@chs.nihon-u.ac.jp

\section{A tabele of content \\ Scheme S1. Synthesis of the modified nucleoside triphosphate (dU ${ }^{\text {gu }} T P$ ).}

Table S1. The 10 most common sequences derived from the $\mathrm{U}^{\text {ad }}$ modified ssDNA library.

Figure S1. An illustration of the aptamer SELEX process in this report.

Figure S2. Representative SPR sensorgrams showing the interaction of aptamers IgA ${ }^{\text {ad1 }}-\operatorname{Ig} A^{\text {ad5 }}$ targeting SIgA.

Figure S3. SPR response curve of the interaction between the SIgA, several types of IgG or serum IgA and the aptamer IgA $\mathrm{A}^{\text {ad4 }}$.

Figure S4. Sequence optimization of sAA-binding aptamers for the FP assay.

Figure S5. Sequence optimization of SIgA-binding aptamers for the FP assay.

Figure S6. Representative SPR sensorgrams showing the interaction between (a) sAA and AMY ${ }^{\text {ad1-2-3 }}$ and (b) SIgA and IgA gul-3-3 $^{\text {. }}$ Figure S7. (a) Representative SPR sensorgrams showing the interaction between SIgA and IgA gu1-3-3 or IgA ${ }^{\text {gu1-3-3N }}$. (b) FP calibration curves of the fluorescent-labeled $\operatorname{Ig} \mathrm{A}^{\text {gul-3-3 }}$ and $\operatorname{Ig} \mathrm{A}^{\text {gul-3-3N }}$.

Figure S8. (a) Random region sequence comparison between $\operatorname{Ig} \mathrm{A}^{\text {ad4 }}$ and $\operatorname{Ig} \mathrm{A}^{\text {gul }}$ (b) The predicted secondary structure of $\operatorname{Ig} \mathrm{A}^{\text {ad4 }}$ and $\operatorname{Ig} \mathrm{A}^{\mathrm{gu} 1}$. 


\section{SYNTHESIS OF THE MODIFIED NUCLEOSIDE TRIPHOSPHATE (dU $\left.{ }^{\mathrm{gu} T P}\right)$}

(1) General

NMR spectra were measured using a JNM-ECS 400 MHz NMR instrument (JEOL Ltd., Tokyo, Japan). ESI-mass spectra were recorded on an API 2000 mass spectrometer (Applied Biosystems Inc., Tokyo, Japan). Reverse-phase high-performance liquid chromatography (HPLC) analyses were performed using a HPLC system from JASCO Corporation, Tokyo, Japan. Reverse-phase medium-pressure chromatography (MPLC) was performed using an YFLC-Wprep System (Yamazen Corporation, Osaka, Japan).

\section{(2) Materials}

2,6-Dichloropurine, 2,2'-dipyridyl disulfide, $n$-tributylamine and trifluoroacetic acid (TFA) were purchased from Tokyo Chemical Industry Co., Ltd. (Tokyo, Japan). Acetonitrile and methanol for liquid chromatography LiChrosolv ${ }^{\circledR}$ were purchased from Merck Millipore (Darmstadt, Germany). Acetic acid, acetone, acetonitrile, chloroform $\left(\mathrm{CH}_{3} \mathrm{Cl}\right)$, diethyl ether, $N, N$-dimethylformamide (DMF), ethylenediamine, hydrochloric acid, imidazole, 2-methoxyethanol, phosphoryl chloride, pyridine, sodium hydroxide ( $\mathrm{NaOH}$ ), triethylamine (TEA), trimethyl phosphate, and triphenylphosphine $\left(\mathrm{PPh}_{3}\right)$ were purchased from Wako Pure Chemical Industries, Ltd. (Osaka, Japan). Di-tert-butyl dicarbonate $\left((\mathrm{Boc})_{2} \mathrm{O}\right)$, 1-hydroxybenzotriazole hydrate $\left(\mathrm{HOBt} \cdot \mathrm{H}_{2} \mathrm{O}\right), \mathrm{N}, \mathrm{N}$-diisopropylethylamine (DIPEA), and benzotriazol-1-yloxy-tri(pyrrolidino)phosphonium hexafluorophosphate (PyBOP) were purchased from Watanabe Chemical Industries, Ltd. (Hiroshima, Japan). (E)-5-(2-Carboxyvinyl)-2'-deoxyuridine was obtained from Berry \& Associates, Inc. (MI, USA).

\section{(3) Chemical syntheses}

The synthetic route of $\mathbf{d U}^{\text {gu}} \mathbf{T P}$ is depicted in Scheme $\mathrm{S} 1$.

Synthesis of compound G1: A solution of di-tert-butyl dicarbonate $(5.00 \mathrm{~g}, 22.9 \mathrm{mmol})$ in $\mathrm{CHCl}_{3}(20 \mathrm{~mL})$ was added to a solution of ethylenediamine $(7.0 \mathrm{~mL}, 105 \mathrm{mmol})$ in $\mathrm{CHCl}_{3}(120 \mathrm{~mL})$ and stirred at room temperature for $24 \mathrm{~h}$. The reaction mixture was filtered in vacuo, and the filtrate was evaporated to afford $\mathbf{G 1}(3.57 \mathrm{~g}, 97 \%) ;{ }^{1} \mathrm{H} \mathrm{NMR}\left(400 \mathrm{MHz}, \mathrm{CDCl}_{3}\right) \delta 3.17(2 \mathrm{H}, \mathrm{q}) 2.79(2 \mathrm{H}, \mathrm{t})$ $1.44(9 \mathrm{H}, \mathrm{s})$; ESI-MS (positive ion mode) $\mathrm{m} / \mathrm{z}$, found $=161.3$, calculated for $\left[(\mathrm{M}+\mathrm{H})^{+}\right]=161.1$.

Synthesis of compound G2: 2,6-Dichloropurine (1.00 g, $5.29 \mathrm{mmol})$ was dissolved in $11 \mathrm{~mL}$ of $2 \mathrm{M} \mathrm{NaOH}$ (aq.) and the mixture was refluxed at $90^{\circ} \mathrm{C}$ for $3 \mathrm{~h}$. The reaction mixture was cooled to room temperature and filtered in vacuo. The residue was dissolved in water, and the $\mathrm{pH}$ was adjusted to 3-4 using an aqueous $\mathrm{HCl}$ solution $(6 \mathrm{M})$. The resulting suspension was filtered in vacuo to afford compound G2 $(720 \mathrm{mg}, 79 \%) ;{ }^{1} \mathrm{H}$ NMR $\left(400 \mathrm{MHz}\right.$, DMSO- $\left.d_{6}\right) \delta 8.29(1 \mathrm{H}, \mathrm{s}$ ); ESI-MS (positive ion mode) $\mathrm{m} / z$, found = 171.0 , calculated for $\left[(\mathrm{M}+\mathrm{H})^{+}\right]=171.0$.

Synthesis of compound G3: A solution of compound G1 (3.28 g, $20.5 \mathrm{mmol})$ in 2-methoxyethanol (1.0 $\mathrm{mL})$ was added to a solution of compound $\mathbf{G 2}(870 \mathrm{mg}, 5.10 \mathrm{mmol})$ in 2-methoxyethanol $(5.0 \mathrm{~mL})$, and the mixture was refluxed at $130{ }^{\circ} \mathrm{C}$ for $1.5 \mathrm{~h}$. The reaction mixture was cooled to room temperature, evaporated to dryness, and then recrystallized from chloroform. Compound $\mathbf{G 3}$ was obtained after filtration in vacuo $(1.12 \mathrm{~g}, 74 \%)$; ${ }^{1} \mathrm{H}$ NMR $\left(400 \mathrm{MHz}, \mathrm{CD}_{3} \mathrm{OD}\right) \delta 7.34(1 \mathrm{H}, \mathrm{s}) 3.46(2 \mathrm{H}, \mathrm{t}) 3.27(2 \mathrm{H}, \mathrm{t}) 1.41$ (9H, s); ESI-MS (positive ion mode) $\mathrm{m} / z$, found $=295.3$, calculated for $\left[(\mathrm{M}+\mathrm{H})^{+}\right]=295.2$.

Synthesis of compound G4: Compound G3 (500 mg, $1.70 \mathrm{mmol})$ was dissolved in TFA/MeOH $(5: 1,18 \mathrm{~mL})$ and the mixture was stirred at room temperature for $1 \mathrm{~h}$. The reaction mixture was evaporated to dryness, and then recrystallized from diethyl ether. Compound G4 was isolated after filtration in vacuo $(467 \mathrm{mg}, 89 \%) ;{ }^{1} \mathrm{H}$ NMR $\left(400 \mathrm{MHz}, \mathrm{D}_{2} \mathrm{O}\right) \delta 8.12(1 \mathrm{H}, \mathrm{s}) 3.71(2 \mathrm{H}, \mathrm{t}) 3.27(2 \mathrm{H}$, $\mathrm{t}$ ); ESI-MS (positive ion mode) $\mathrm{m} / \mathrm{z}$, found $=195.1$, calculated for $\left[(\mathrm{M}+\mathrm{H})^{+}\right]=195.1$.

Synthesis of nucleoside $\boldsymbol{d U}^{\text {gu}}$ : To a solution of compound (E)-5-(2-carboxyvinyl)-2'-deoxyuridine (101 mg, $\left.339 \mu \mathrm{mol}\right)$ in dry DMF $(1.0 \mathrm{~mL}), \mathrm{HOBt} \cdot \mathrm{H}_{2} \mathrm{O}(68.0 \mathrm{mg}, 444 \mu \mathrm{mol})$, PyBOP $(229 \mathrm{mg}, 440 \mu \mathrm{mol})$, and DIPEA $(790 \mu \mathrm{L}, 4.51 \mathrm{mmol})$ were added. A solution of compound G4 $(171 \mathrm{mg}, 412 \mu \mathrm{mol})$ and DIPEA $(790 \mu \mathrm{L}, 4.51 \mathrm{mmol})$ in dry DMF $(500 \mu \mathrm{L})$ was then added and the resulting mixture was stirred at room temperature for $1 \mathrm{~h}$. The reaction mixture was evaporated to dryness, and the residue was suspended using $\mathrm{CHCl}_{3}$. Compound $\mathbf{d U}^{\mathrm{gu}}$ was isolated after in vacuo filtration of the resulting suspension $(147 \mathrm{mg}, 91 \%) ;{ }^{1} \mathrm{H} \mathrm{NMR}(400 \mathrm{MHz}$, DMSO-d $\left.d_{6}\right) \delta 8.28(1 \mathrm{H}, \mathrm{s}) 7.62(1 \mathrm{H}, \mathrm{s}) 7.13(1 \mathrm{H}, \mathrm{d}) 7.04(1 \mathrm{H}, \mathrm{d}) 6.14(1 \mathrm{H}, \mathrm{t}) 5.26(1 \mathrm{H}, \mathrm{d}) 4.26(1 \mathrm{H}, \mathrm{t}) 4.10(1 \mathrm{H}, \mathrm{q}) 3.79(1 \mathrm{H}, \mathrm{q}) 3.67-$ $3.56(2 \mathrm{H}, \mathrm{m}) 3.17(2 \mathrm{H}, \mathrm{d}) 2.15(2 \mathrm{H}, \mathrm{q})$; ESI-MS (positive ion mode) $\mathrm{m} / z$, found $=475.1$, calculated for $\left[(\mathrm{M}+\mathrm{H})^{+}\right]=475.2$.

Synthesis of compound G5: Compound $\mathbf{d U}^{\text {gu }}$ was twice co-evaporated with dry pyridine $(30 \mathrm{~mL})$. To a solution of compound $\mathbf{d U}^{\mathrm{gu}}$ $(101 \mathrm{mg}, 213 \mu \mathrm{mol})$ in dry trimethyl phosphate $(21 \mathrm{~mL})$, phosphoryl chloride $(400 \mu \mathrm{L}, 4.29 \mathrm{mmol})$ was added and stirred in an ice bath for $2.5 \mathrm{~h}$. Then, additional phosphoryl chloride $(200 \mu \mathrm{L}, 2.15 \mathrm{mmol})$ was added, and the reaction mixture was further stirred in an ice bath for $8.5 \mathrm{~h}$. Iced water $(10 \mathrm{~mL})$ was added to the reaction mixture followed by $10 \mathrm{~min}$ stirring, and TEA $(680 \mu \mathrm{L}, 4.29$ $\mathrm{mmol}$ ) was further added. Stirring continued for $15 \mathrm{~min}$ till quench. The reaction mixture was evaporated and the residue was suspended using acetonitrile and diethyl ether. The suspension was filtered in vacuo, and the residue was purified by anion exchange chromatography to afford compound G5 $\left(23 \mathrm{mg}, 20 \%\right.$ ); ESI-MS (negative ion mode) $\mathrm{m} / \mathrm{z}$, found $=553.0$, calculated for $\left[(\mathbf{M}-\mathrm{H})^{-}\right]=$ 553.1 .

Synthesis of compound G6: Compound G5 was three times co-evaporated with dry pyridine $(5.0 \mathrm{~mL})$. To a solution of compound G5 $(43.0 \mathrm{mg}, 78.7 \mu \mathrm{mol})$ in dry DMF $(2.0 \mathrm{~mL})$, TEA $(72.0 \mu \mathrm{L}, 519 \mu \mathrm{mol})$ was added and stirring followed for $5 \mathrm{~min}$. Then, imidazole $(24.0 \mathrm{mg}, 353 \mu \mathrm{mol}), \mathrm{PPh}_{3}(36.0 \mathrm{mg}, 137 \mu \mathrm{mol})$, and 2,2'-dipyridyl disulfide $(29.0 \mathrm{mg}, 132 \mu \mathrm{mol})$ were added and stirred at room temperature for $8 \mathrm{~h}$. The reaction mixture was then added to a solution of anhydrous sodium perchlorate $(97.0 \mathrm{mg}, 792 \mu \mathrm{mol}) \mathrm{in}$ dry acetone $(18 \mathrm{~mL})$, dry diethyl ether $(27 \mathrm{~mL})$ and dry TEA $(2.0 \mathrm{~mL})$, and the mixture was allowed to rest at $4{ }^{\circ} \mathrm{C}$ for $30 \mathrm{~min}$. The precipitate was washed 5 times with dry diethyl ether $(40 \mathrm{~mL})$ to provide compound $\mathbf{G 6}$ as crude material. 
Synthesis of triphosphate $\mathbf{d U}^{\text {gu }} \mathbf{T P}$ : The impure compound $\mathbf{G 6}$ was twice co-evaporated with dry pyridine (5.0 $\left.\mathrm{mL}\right)$. To a solution of G6 $(78.7 \mu \mathrm{mol})$ in dry DMF $(1.0 \mathrm{~mL})$, dry $n$-tributylamine $(75.0 \mu \mathrm{L}, 315 \mu \mathrm{mol})$ and dry $n$-tributylamine pyrophosphate $(800 \mu \mathrm{L}$ of a $0.5 \mathrm{M}$ solution in DMF; $393 \mu \mathrm{mol}$ ) were added and stirred at room temperature for $9 \mathrm{~h}$. The reaction was quenched with triethylammonium bicarbonate $(1.0 \mathrm{M}$ aqueous solution) $(5.0 \mathrm{~mL})$. The mixture was evaporated, the residue was dissolved in water, and then washed twice with diethyl ether. The aqueous layer was concentrated and purified by anion exchange chromatography and reversedphase MPLC to yield $\mathbf{d U ^ { g u }} \mathbf{T P}\left(14 \mathrm{mg}, 25 \%\right.$ from G5); ESI-MS (negative ion mode) $\mathrm{m} / z$, found $=712.9$, calculated for $\left[(\mathbf{M}-\mathrm{H})^{-}\right]=$ 713.1.

\section{SUPPLEMENTARY DATA}
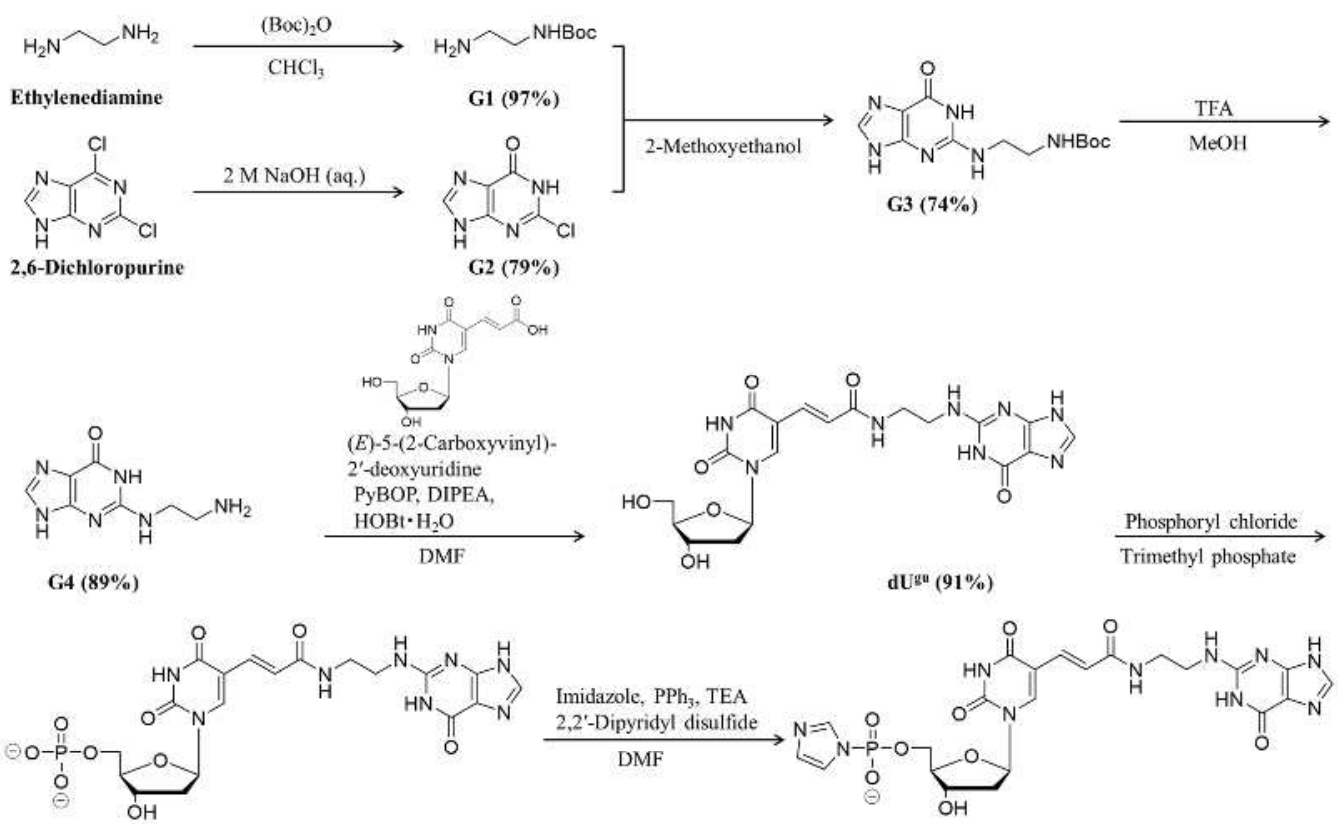

G5 (20\%)

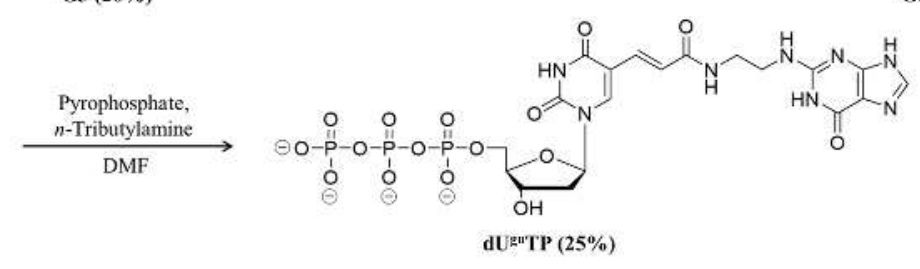

Scheme S1. Synthesis of nucleoside dU ${ }^{\mathrm{gu}} \mathrm{TP}$. 
Table S1. The 10 most common sequences derived from the $U^{\text {ad }}$ modified ssDNA library.

\begin{tabular}{|l|l|l|}
\hline Clone name & Sequence ratio & \\
\hline Ig $^{\text {ad }}$ & Random region sequence & \\
\hline Ig $^{\text {ad2 }}$ & $7.5 \%$ & GtAtAtCAAGCAGAtGtGttCACttGGGGA \\
\hline IgA $^{\text {ad3 }}$ & $7.2 \%$ & AAAGAtAtGCtAAGAtAGAtAGtttGGCtt \\
\hline IgA $^{\text {ad4 }}$ & $7.1 \%$ & ACCtGtACtGGttAttAtGCCtGCCAACAt \\
\hline IgA $^{\text {ad5 }}$ & $5.4 \%$ & tttAtACGtAtGGACttAGGCtttGttAtA \\
\hline IgA $^{\text {ad6 }}$ & $5.1 \%$ & CtAtCtGttttAtCAAttGtAGCAAGttAt \\
\hline IgA $^{\text {ad7 }}$ & $4.6 \%$ & AAtCCGGCtGtAAtGCttAttAtGCCtGCG \\
\hline IgA $^{\text {ad8 }}$ & $4.2 \%$ & GAtGGAttAtAtGAAGtCttGGGAAGGttt \\
\hline IgA $^{\text {ad9 }}$ & $3.9 \%$ & AAAGttGCCGtACGCGGGtAtGCCtGGGtt \\
\hline IgA $^{\text {ad10 }}$ & $3.0 \%$ & AAGttCtAGtGAtAtACAGttACtAtACCt \\
\hline
\end{tabular}

(a) Sequence ratio was defined as the ratio of the sequence to the total number of sequences, which was generated by next generation sequencer. (b) " $\mathrm{t}$ " indicates $\mathrm{U}^{\mathrm{ad}}$.

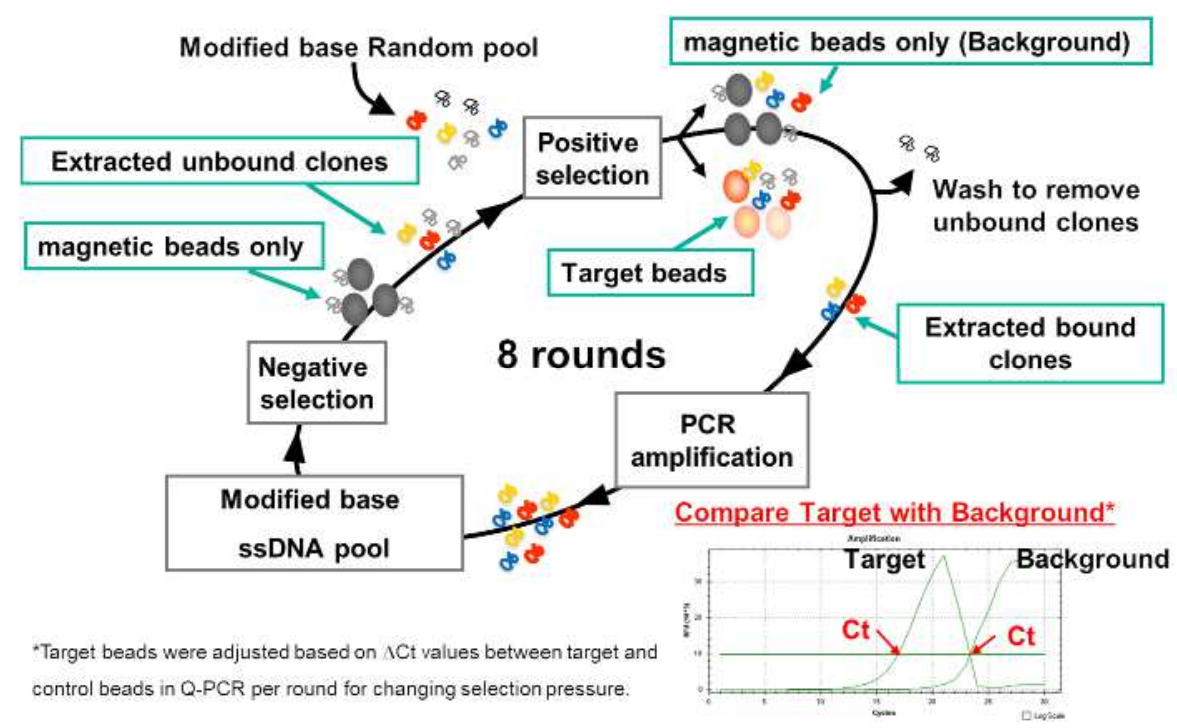

Figure S1. An illustration of the aptamer SELEX process in this report.

The quantity of target beads of positive selection step was lowered each round in response to the previous round of target/background ratio according to Gold et. al. ${ }^{22}$ 

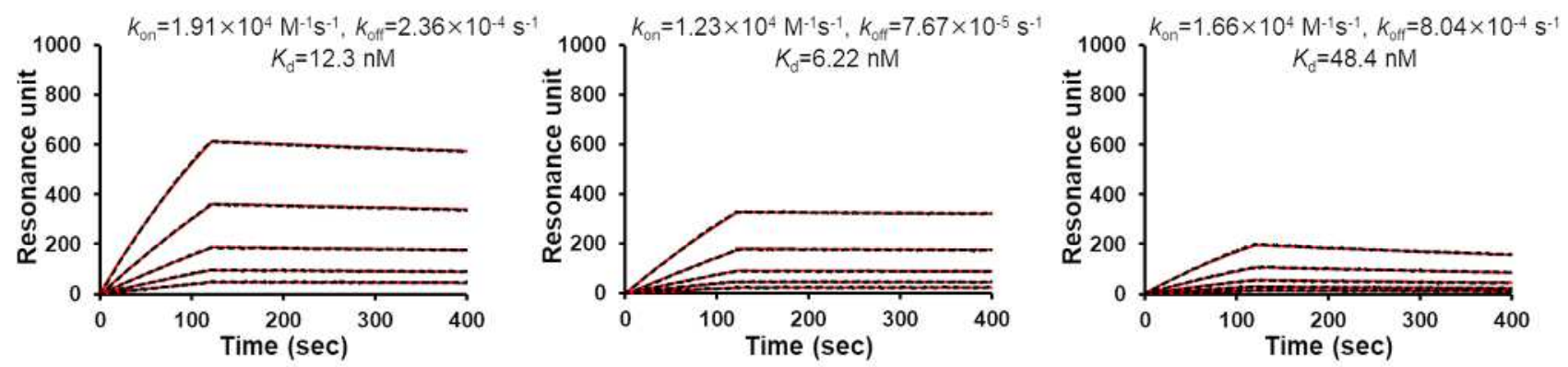

$\lg \mathrm{A}^{\mathrm{ad} 4}$
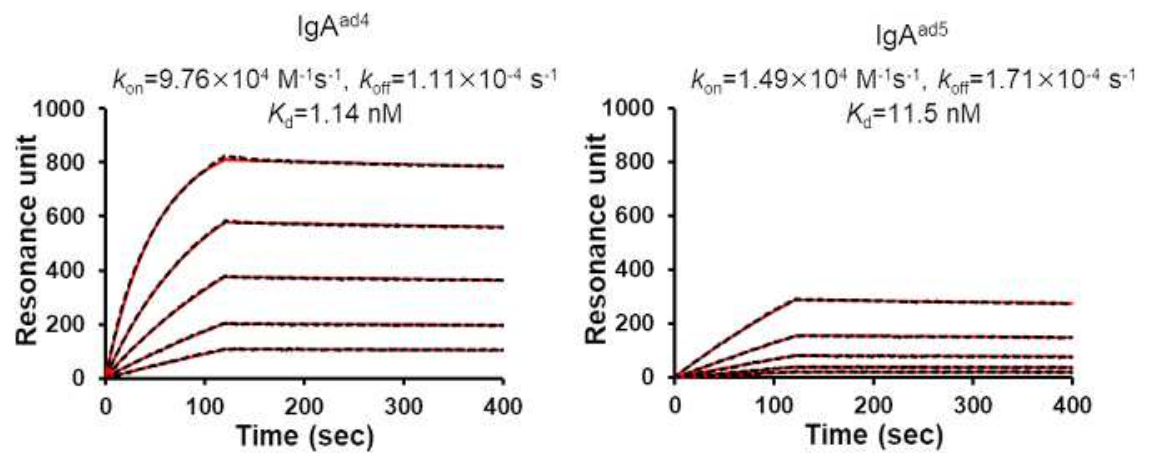

Figure S2. Representative SPR sensorgrams showing the interaction of aptamers $\operatorname{Ig} A^{\text {ad1 }}-\operatorname{Ig} A^{\text {ad5 }} \operatorname{targeting} \operatorname{SIg} A$. Measurements were performed with multicycle kinetics and various SIgA concentrations (12.5-200 nM) were injected over the respective aptamer-immobilizing sensor chip for $120 \mathrm{~s}$ at a flow rate of $50 \mu \mathrm{L} / \mathrm{min}$. The black dot line represents the measured curve, and the red represents the fitting curve. The $K_{\mathrm{d}}$ values of aptamers IgA ${ }^{\text {ad1 }}-\operatorname{Ig} \mathrm{A}^{\text {ad5 }}$ were $12.3 \mathrm{nM}, 6.22 \mathrm{nM}, 48.4 \mathrm{nM}, 1.14 \mathrm{nM}, 11.5 \mathrm{nM}$, respectively.

(a)

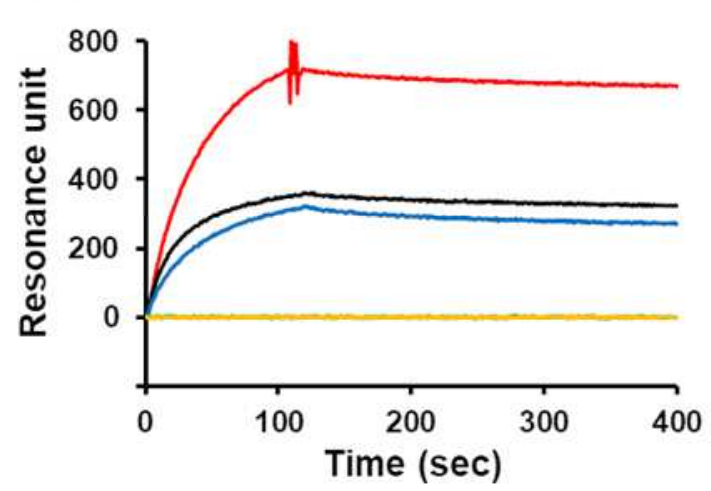

(b)

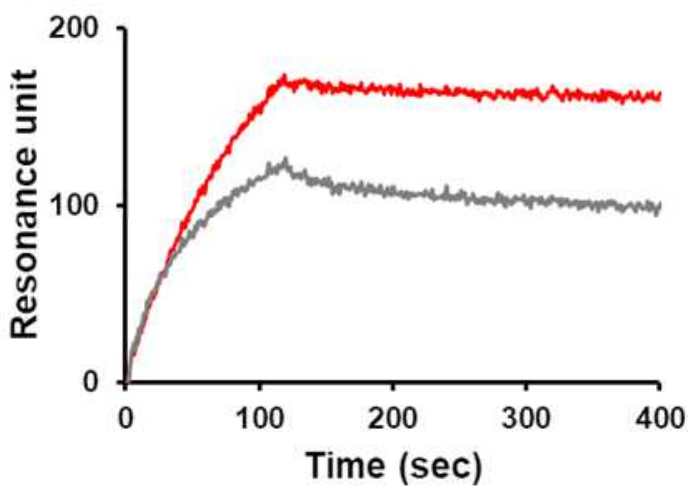

Figure S3. (a) SPR response curve of the interaction between the SIgA or several types of $\operatorname{IgG}$ and the aptamer $\operatorname{Ig} \mathrm{A}^{\text {ad4 }}$. SIgA, IgG1 kappa, $\mathrm{IgG}$, or IgG-Fc (each of $400 \mathrm{nM}$ ) were injected over the respective aptamer-immobilizing sensor chips for $120 \mathrm{~s}$ at a flow rate of $50 \mu \mathrm{L} / \mathrm{min}$. The red line represents the SIgA measured curve, while the black and blue lines represent the IgG1 kappa and IgG recorded curves, respectively. The green and orange lines represent the IgG-Fc1 and IgG-Fc2 measured curves, respectively. (b) SPR response curve of the interaction between the SIgA or serum IgA and the aptamer IgA ${ }^{\text {ad } 4}$. SIgA or serum $\operatorname{IgA}$ (each of $50 \mu \mathrm{g} / \mathrm{mL}$ ) was injected over the respective aptamerimmobilizing sensor chips for $120 \mathrm{~s}$ at a flow rate of $50 \mu \mathrm{L} / \mathrm{min}$. The red line represents the SIgA measured curve, and the gray lines represent the serum IgA measured curves, respectively. 
(a)

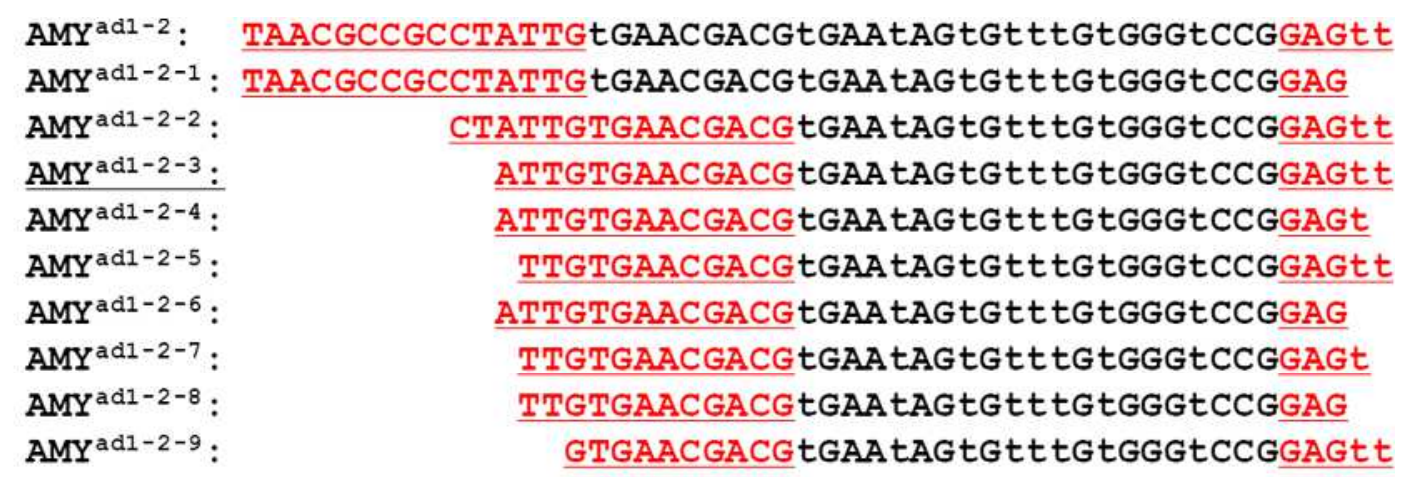

(b)

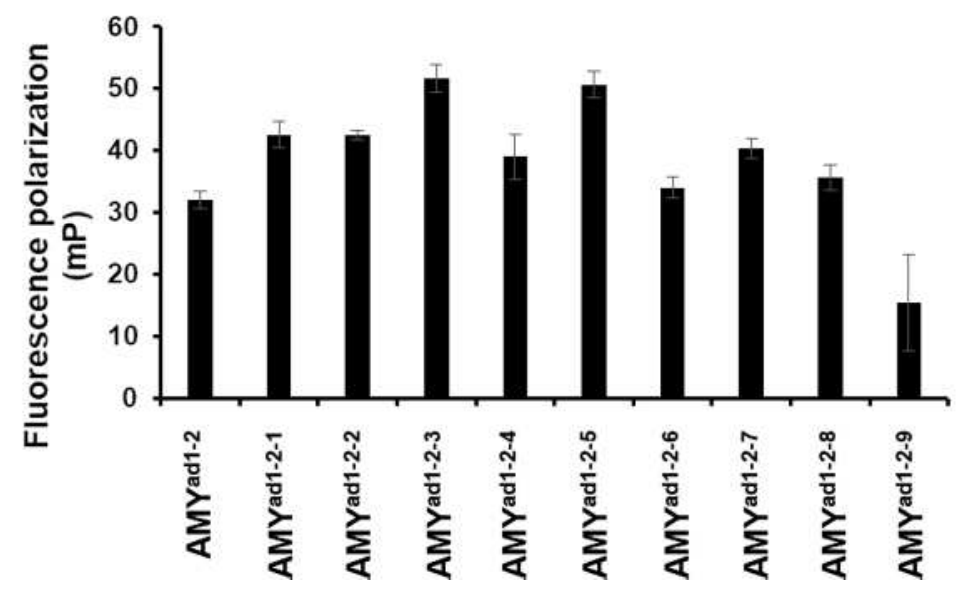

Figure S4. Sequence optimization of sAA-binding aptamers for the FP assay. (a) Sequences of the AMY ad1-2 truncated aptamers for the FP measurement. Sequences are aligned in the 5' to 3' direction. Underlined regions derive from the primer or primer-binding regions. (t) letters indicate the $\mathrm{U}^{\mathrm{ad}}$. The prepared clones introducing the fluorescence dye (TYE665) at the 5'-end, are shown in the table. $10 \mathrm{nM}$ of the fluorescent-labeled clones were denatured at $95{ }^{\circ} \mathrm{C}$ for $5 \mathrm{~min}$, folded at $95^{\circ} \mathrm{C}$ for $5 \mathrm{~min}$, and then incubated with the target samples (sAA; $10 \mathrm{nM}$ and SIgA; $1 \mu \mathrm{M}$ ) in SB2 at $25^{\circ} \mathrm{C}$ for 5 min. After incubation, the samples were measured using FP spectroscopy. (b) Variation of the FP arising from the interaction between the sAA and the AMY ${ }^{\text {ad1-2 }}$ truncated aptamers. The AMY ad1-2-3 displayed the most FP signal changes to sAA-binding. 
(a)

$$
\begin{aligned}
& \text { IgAgui-3: GCAATCTCCCTAATCtGCtGAtGtttgtAtttCAAAttAGC } \\
& \text { IgAgu1-3-1: GCAATCTCCCTAATCtGCtGAtGtttGtAtt tCAAAtt } \\
& \text { IgAgu1-3-2: CAATCTCCCTAATCtGCtGAtGtttgtAtttCAAAtt } \\
& \text { IgAgu1-3-3: AATCTCCCTAATCtGC tGAtgtttgtAtttCAAAtt } \\
& \text { IgAgu1-3-4: TCTCCCTAATCtGCtGAtGtttgtAtt tCAAAt } \\
& \text { IgAgui-3-5: TCCCTAATCTGCtGAtgtttgtAttCAAAt } \\
& \text { IgAgu1-3-6: } \quad \text { CCTAATCTGCTGAtGtttgtAttCAAAtt } \\
& \text { IgAgu1-3-7: TCCCTAATCTGCtGAtGtttgtAttCAAAt }
\end{aligned}
$$

(b)

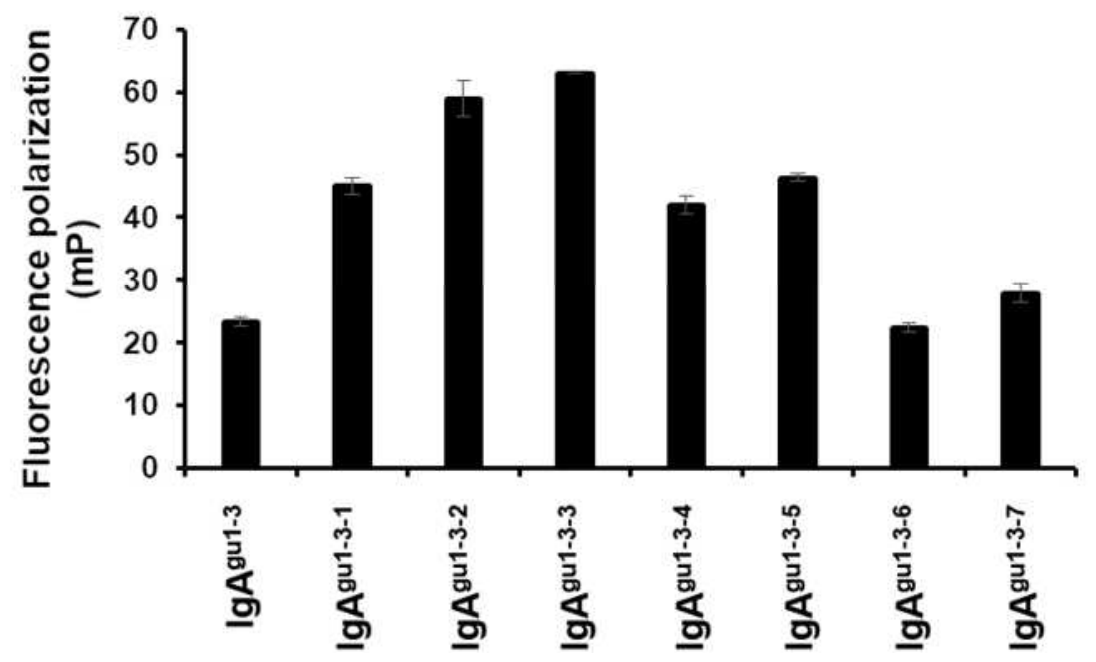

Figure S5. Sequence optimization of SIgA-binding aptamers for the FP assay. (a) Sequences of the IgA ${ }^{\text {gu1-3 }}$ truncated aptamers for the FP measurement. Sequences are aligned in the 5' to 3' direction. Underlined regions derive from the primer or primer-binding regions. (t) letters indicate $\mathrm{U}^{\mathrm{gu}}$. The prepared clones introducing the fluorescence dye (TYE665) at the 5'-end, are shown in the table. Target samples (sAA; 10 $\mathrm{nM}$ and SIgA; $1 \mu \mathrm{M}$ ) were denatured at $95^{\circ} \mathrm{C}$ for $5 \mathrm{~min}$, folded at $95^{\circ} \mathrm{C}$ for $5 \mathrm{~min}$, and then incubated with $10 \mathrm{nM}$ of the fluorescent-labeled clones in SB2 at $25^{\circ} \mathrm{C}$ for $5 \mathrm{~min}$. After incubation, the samples were measured using FP spectroscopy. (b) Variation of the FP arising from the interaction between the SIgA and the $\operatorname{IgA}^{\text {gul-3 }}$ truncated aptamers. The $\operatorname{IgA}{ }^{\text {gu1-3-3 }}$ displayed the most FP signal changes to SIgA-binding. 

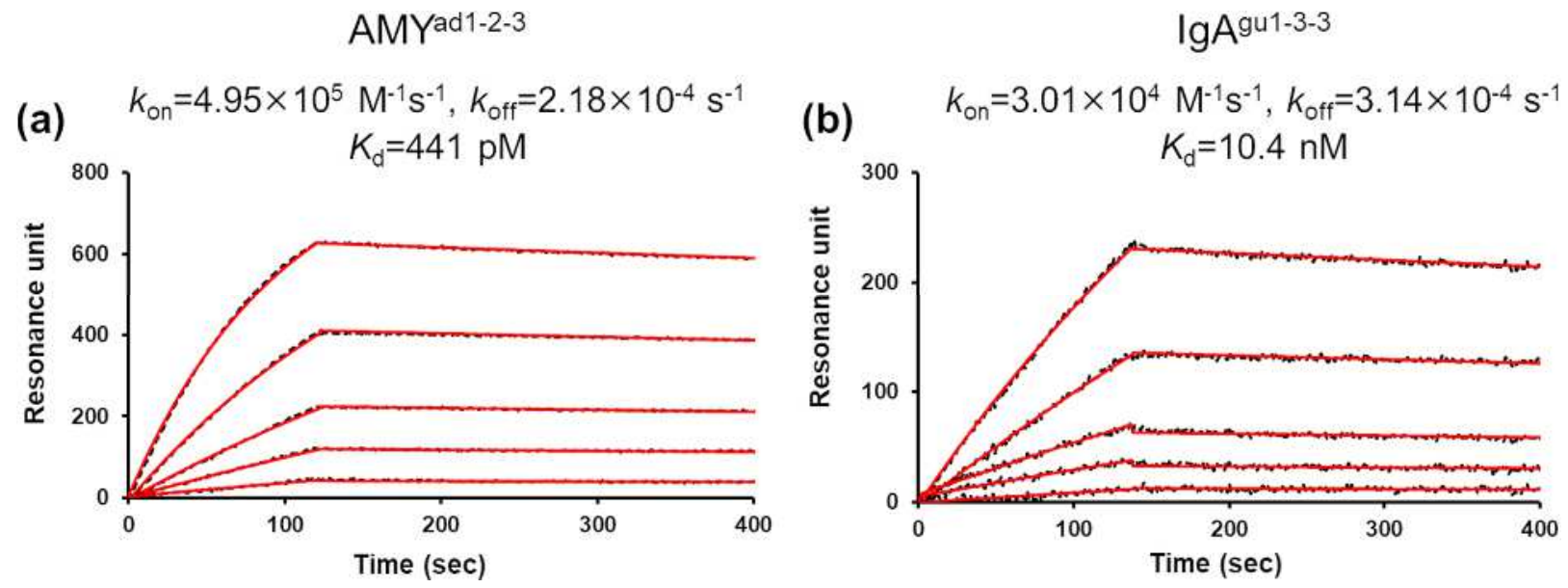

Figure S6. Representative SPR sensorgrams showing the interaction between (a) SAA and AMY ${ }^{\text {ad1-2-3 }}$ and (b) SIgA and IgA ${ }^{\text {gu1-3-3 }}$. Measurements were performed with multicycle kinetics and various concentrations of sAA (1.25-20 nM) or SIgA (6.25-100 nM) were injected over the respective aptamer-immobilizing sensor chip for $120 \mathrm{~s}$ at a flow rate of $50 \mu \mathrm{L} / \mathrm{min}$. The black dashed line represents the measured curve and the red line represents the fitting curve.

(a)

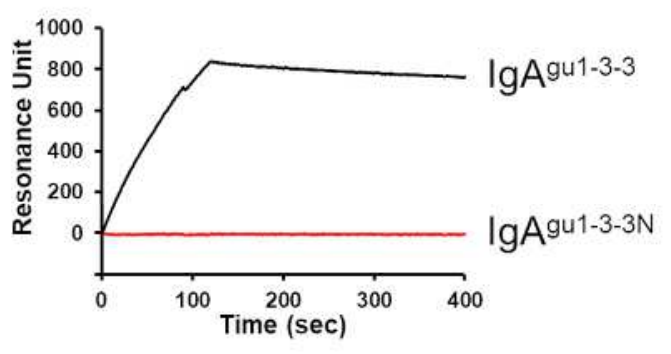

(b)

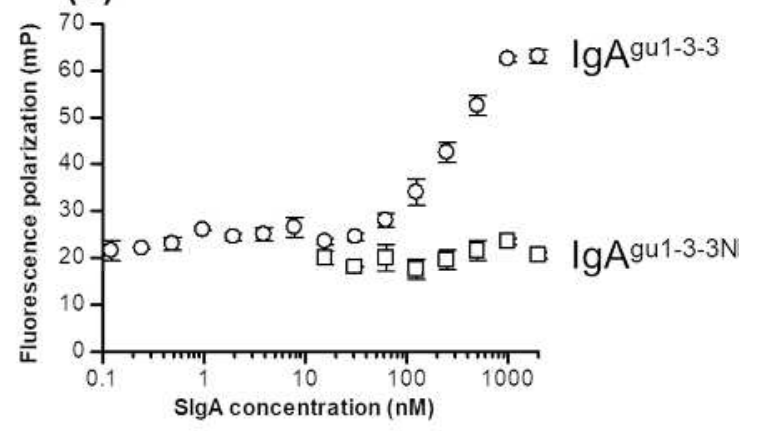

\section{(c) IgAgu1-3-3 : AATCTCCCTAATCtGCtGAtGtttGtAtttCAAAtt IgA ${ }^{\text {gu1-3-3N: }}$ AATCTCCCTAATCTGCTGATGTTTGTATTTCAAATT}

Figure S7. (a) Representative SPR sensorgrams showing the interaction between SIgA and $\operatorname{Ig} \mathrm{A}^{\text {gu1-3-3 }}$ or $\operatorname{Ig} \mathrm{A}^{\text {gu1-3-3N }}$. Measurements were performed with concentrations of SIgA $(400 \mathrm{nM})$ were injected over the respective aptamer-immobilizing sensor chip for $120 \mathrm{~s}$ at a flow rate of $50 \mu \mathrm{L} / \mathrm{min}$. The black line represents the $\operatorname{IgA}^{\text {gul-3-3 }}$ and the red line represents the $\operatorname{IgA}^{\text {gu1-3-3N }}$. (b) FP calibration curves of the fluorescent-labeled IgA $\mathrm{A}^{\text {gu1-3-3 }}$ and $\operatorname{IgA}^{\text {gu1-3-3N }}$ in SB2. IgA $\mathrm{A}^{\text {gu1-3-3 }}$ was incubated with $0.12-2000 \mathrm{nM}$ and $\operatorname{Ig} \mathrm{A}^{\text {gu1-3-3N }}$ was incubated with $15.6-2000 \mathrm{nM}$ of the SIgA in SB2 and measured. The open circles represent the $\operatorname{Ig} A^{\text {gul-3-3 }}$ and open squares represent $\operatorname{Ig} \mathrm{A}^{\text {gu1-3-3N }}$, respectively. (c) Sequences of the $\operatorname{Ig} \mathrm{A}^{\text {gu1-3-3 }}$ and $\operatorname{Ig} \mathrm{A}^{\text {gu1-3-3N }}$. Sequences are aligned in the $5^{\prime}$ to $3^{\prime}$ direction. $(\mathrm{t})$ letters indicate the $\mathrm{U}^{\mathrm{gu}}$. 
(a)

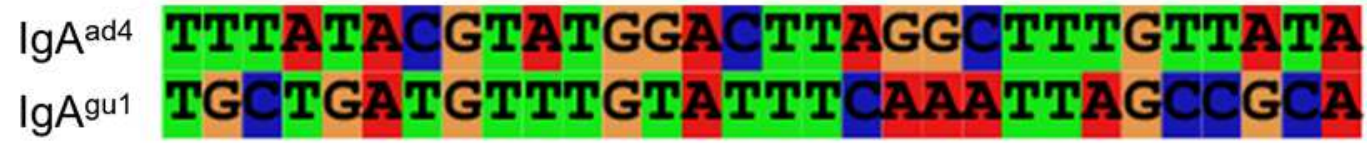

(b)

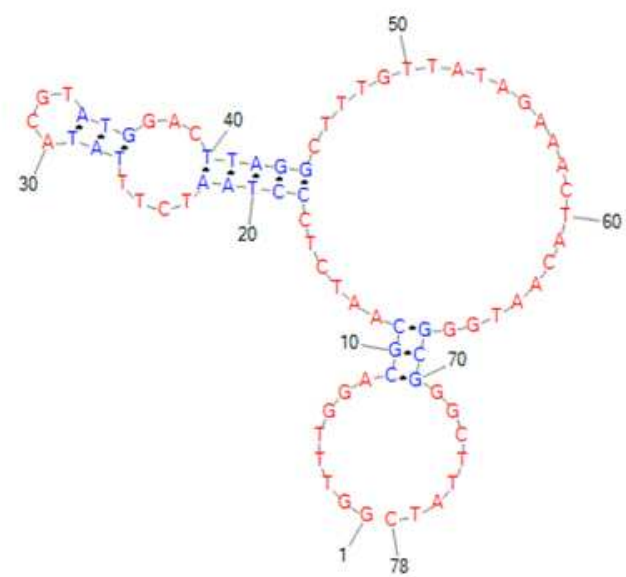

$\lg \mathrm{A}^{\text {ad4 }}$

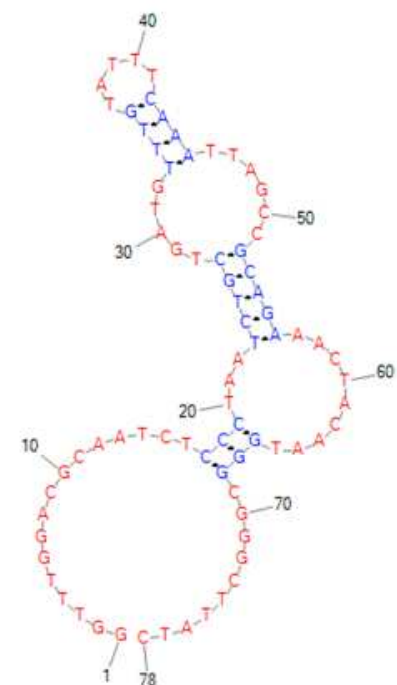

$\lg A^{g u 1}$

Figure S8. (a) Random region sequence comparison between $\operatorname{Ig} A^{\text {add }}$ and $\operatorname{Ig} A^{\text {gu1 }}$ (b) The predicted secondary structure of $\operatorname{Ig} A^{\text {ad4 }}$ and $\operatorname{Ig} A^{\text {gu1 }}$ using VALFold program and the general DNA parameters. ${ }^{34,35}$ 